\title{
Dairy Marketing Strategies in the Context of Globalization: Issues and Challenges
}

\author{
Ashraf Imam, M N Zadeh, and Laxmi Rani Dubey
}

\begin{abstract}
Globalization remains a key force in driving Indian economy and India's dairy industry products acknowledge the demands and preferences around the world by the consumers. New imperatives like production systems issues such as animal welfare and environmental footprint, and also product quality attributes such as traceability and product safety. Dairy farmers need immediate solutions to retain their competitiveness and access to global markets and for this we need innovation which is important that the industry maintains a unified approach and adapts to the changing nature of the people involved. However, with increased pressure on local and central government on environmental management, there is need to recruit additional and more skilled people into the dairy industry. The longer-term success of the dairy industry will depend on attracting and retaining talented people and growing these individuals using effective skills development programmes especially for marketing strategies department. So this paper present marketing Strategies which focus on the actions the dairy industry needs to take to influence perceptible from the dairy farming system to the world.
\end{abstract}

Index Terms-Globalization, Indian Economy, Dairy Industry, Dairy product, Sustainability, Marketing Strategies.

\section{INTRODUCTION}

Globalization is one of the greatest strategic challenges for all Industries as well as dairy Industry. Globalization has increased significantly over the last decade, and despite financial crises and recession in many parts of the world globalization will likely continue - albeit with less force than before. Globalization is far from a unique concept. Globalization can also have multiple dimensions and applications. In this context, globalization is defined as follows:

Globalization is the continuing development of a firm's international involvement concerning geographical markets, products, management, resources (labour, raw materials etc.) for the purpose of optimization of the international market opportunities and threats. Globalization is not just about selling to foreign customers. It is also about recognizing the international competition and to adjust production, resources, investment and organization to these challenges

Ashraf Imam, Ex-Branch Manager-Reliance Life Insurance- Sikandrarao Branch-Aligarh Region and currently enrolled as $\mathrm{PhD}$ student -Department of Commerce-Aligarh Muslim University-Aligarh, UP-India. (imamashraf1@rediffmail.com)

M N Zadeh, MS.c Dairy Economic ( Final)-N.D.R.I-Karnal-India. (email: sofya_nasiry@yahoo.com)

Laxmi Rani Dubey, PhD Dairy Economic (First Year) )-N.D.R.I-Karnal, India (email: laxmirani.d@gmail.com).

\section{OUtLINE OF DAIRY AROUND THE WORLD}

Since 1980 the demand for the dairy products grew especially in Asian region from $32 \mathrm{~kg}$ per capita in 1981 to 64 kg per capita in 2007, the Asian consumers presented almost a half of the world demand for milk and milk products. Growing income and change in food composition in China, India and other Asian countries are the factors of the increasing demand (table1). The governmental support of milk consumption like school milk programs and new dairy products supported this expansion (FAO, 2009). This growing demand and higher prices created market opportunities for the local producers and in 2005 Asia became the world largest milk producer with grows $35 \%$ in 1997-2007.

TABLE1. PER CAPITA MILK CONSUMPTION, MILK EQUIVALENTS, 1981 2007

\begin{tabular}{|lllll|}
\hline & $\mathbf{1 9 8 1}$ & $\mathbf{1 9 9 0}$ & $\mathbf{2 0 0 0}$ & $\mathbf{2 0 0 7}$ \\
\hline World & 86 & 80 & 104 & 113 \\
\hline Developed & 222 & 180 & 235 & 248 \\
\hline Developing & 35 & 40 & 56 & 68 \\
\hline China & 3 & 6 & 11 & 22 \\
\hline India & 50 & 63 & 79 & \\
\hline US & 271 & 274 & 287 & 295 \\
\hline EU & $\mathrm{Na}$ & 363 & 469 & 382 \\
\hline
\end{tabular}

During period of higher prices in 2007 many countries used the new built capacities in dairy production especially for the export, with lower prices it became less attractive in 2008 to export, the part of the production returned on the domestic markets and additional lowered the prices. In 2008 the positions of the major exporters have been returned to the traditional exporters like Australia, New Zeeland and USA. Asian market has imported in 2008 about 19 million tones dairy products, concentrated nearby half of the global milk trade. The net export position of Oceania is 14 mill $\mathrm{t}$ and of the EU is 7.8 mill t (FAO, 2009), which shows the dependency of the EU from the consumption and import demand in the Asian countries (Figure 1). In spite of the temporary supply overhang, the world market is still not able to cover growing demand for milk and dairy products because of low productivity. For example, the average yield in Asia is still 0.91 tonnes per animal per year, while in North America in 2007 it was 9,01 tones. Asia has $52 \%$ of global livestock, but only $34 \%$ of the world production. Nearly 80 
percent of overall milk production gains over the past decade were supplied by producers with two to five cows (FAO, 2009). Therefore it is to expect that the middle- and big sized farms would have the cost advantages for the next years and would be the major exporters of milk.

The costs of milk production differ within regions and between regions, the last research of IFCN shows significant cost advantages of larger dairy farms compared to smaller ones (IFCN, 2008).

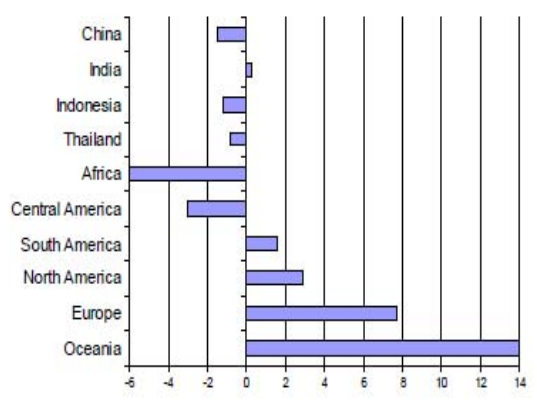

Source: FAO (2009)

Figure 1. Trade Positions in Milk Trade

As global recession has made a negative impact on the affordability as well as demand for dairy products, changing consumer behavior across several markets worldwide, but demand for dairy products began to recover in the latter part of the 2009 and the industry began to witness growth in early 2010. The market for dairy products is forecast to gain momentum over the ensuing years. Global dairy market, over the recent years, expanded mainly due to introduction of new dairy products, like omega-3 fatty acids-enriched milk, and A2 milk, probiotic dairy product and etc that beside health benefit played a vital role in the growth of global dairy market.

The global market for Dairy Products is forecast to reach US $\$ 494$ billion by the year 2015. Recovery in consumption post global recession, continuing population growth, rising demand from developing countries, trade liberalization, and continued growth in advertising are expected to fuel market growth.

\section{OUTLINE OF DAIRY INDUSTRY IN INDIA}

India is the world's largest milk producer, accounting for more than $13 \%$ of world's total milk production. As it is the world's largest consumer of dairy products, but consuming almost $100 \%$ of its own milk production. Dairy products are a major source of cheap and nutritious food to millions of people in India and the only acceptable source of animal protein for large vegetarian segment of Indian population, particularly among the landless, small and marginal farmers and women. In India, about three-fourth of the population live in rural areas and about $38 \%$ of them are poor.

The aim of different activities involves in dairy is alleviating the poverty and unemployment especially in the rural areas in the rain-fed and drought-prone regions. Presently there are around 70,000 village dairy cooperatives across the country. The co-operative societies are federated into 170 district milk producers unions, which is turn has 22-state cooperative dairy federation. Milk production gives employment to more than $72 \mathrm{mn}$ dairy farmers. In terms of total production, India is the leading producer of milk in the world followed by USA. The milk production in 2005-06 is estimated at $97.1 \mathrm{mn}$ MT as compared to $92.5 \mathrm{mn}$ MT in the previous year. This production is expected to increase to $100 \mathrm{mn}$ MT by $2006-07$. Of this total produce of $89 \mathrm{mn}$ cows' milk constitutes $56 \mathrm{mn}$ MT while rest is from other cattle.

Although milk production has grown at a fast pace during the last three decades (courtesy: Operation Flood), but the milk processing industry is small compared to the huge amount of milk produced every year. Only $10 \%$ of all the milk is delivered to some 400 dairy plants. A specific Indian phenomenon is the unorganised sector of milkmen, vendors who collect the milk from local producers and sell the milk in both, urban and rural areas, which handles around $65-70 \%$ of the national milk production. In the organised dairy industry, the cooperative milk processors have a $60 \%$ market share. The cooperative dairies process $90 \%$ of the collected milk as liquid milk whereas the private dairies process and sell only $20 \%$ of the milk collected as liquid milk and $80 \%$ for other dairy products with a focus on value-added products. In the present situation of world market, the milk and dairy market landscape is a dynamic entity within the food industry new opportunities in emerging markets, increasing globalization, changes in consumer demand, nutritional policy and the regulatory environment are among top issues facing the industry. Global Dairy Platform was created to maximize the impact of these changes and promote and protect dairy's position worldwide. With this backdrop India is a very minor player in the world dairy market. India was primarily an import dependent country till early seventies. Most of the demand-supply gaps of liquid milk requirements for urban consumers were met by importing anhydrous milk fat / butter and dry milk powders. But with the onset of Operation Flood Programme, the scenario dramatically changed and commercial imports of dairy products came to a halt except occasional imports of very small quantities. In the 1990s, India started exporting surplus dairy commodities, such as SMP, WMP, butter and ghee.

The Agricultural and Processed Food Products Export Development Authority (APEDA) regulated the export and import of dairy products till early 1990s. However, in the new EXIM Policy announced in April 2000, the Union Government has allowed free import and export of most dairy products. In terms of products, SMP (skimmed milk powder) is the most important product accounting for about $(63 \%)$ of total export volume, followed by ghee and butter $(11.7 \%)$ and WMP (whole milk powder). Export figures clearly demonstrate that the Indian dairy export is still in its infancy and the surpluses are occasional. Global opportunities available to the Indian dairy industry arise primarily out of the availability of a large quantity of competitively priced milk. As the Indian dairy sector produces milk without any subsidies, the country stands to gain from the fair implementation of WTO agreements. 
Therefore to having shared in global market, over viewing the dairy situation, finding problem area and challenges is necessary. Some of the major problems emerging from intensive discussions that needs to be considered as bellow:

1) Lack of quality in dairy product to face challenge with global market

2) milk yield per animal is very low

The demand for quality dairy products is rising in all over the world specially in developing countries, therefore to improve quality of milk and dairy product Indian dairy Industry needs to identify and address quality related problems at every stage from the producer at the village cooperative, to the dairy plant and the process of final delivery to the consumer .Also facilitate improvement of hygiene, sanitation, food safety and operating efficiency in the dairy plants and sensitize dairy personnel to product quality aspects as per international standards. Although for increasing the productivity of milching animal should look scientific practices in milching, adequate availability of fodder in all seasons by better management, and providing sufficient veterinary health services to the dairy cattle. Moreover if India wants to prepare itself to access the global markets, needs possible strategies for takeoff. As per Dairy India 2007 (Sixth Edition). ISBN: 81-901603-1-1. By Sharad Gupta, Dairy India Yearbook, A-25 Priyadarshini Vihar, Delhi, www.DairyIndia.com "The dairy market will more than double by 2011. By then, the organized sector will account for $30 \%$ of milk output and two-thirds will come from the private sector.

\section{DAiry MARKeting STRATEgIES}

Dairy marketing truly came into the public's consciousness with the introduction of the "Got Milk" campaign in 1993. The basic dairy product became associated with a memorable and catchy slogan that helped drive sales. There are many other strategies, though, to market all types of dairy products. These include promotion of nutritional value, appeal to the organic market, and use of social media networks and development of new dairy products.

According to American Marketing Association marketing as "the process of planning and executing the conception, pricing, promotion, and distribution of ideas, goods, and services to create exchanges that satisfy individual and organizational objectives." Marketers use an assortment of strategies to guide how, when, and where product information is presented to consumers. Their goal is to convince consumers to buy a particular brand or product.

Successful marketing strategies create a desire for a product. A marketer, therefore, needs to understand consumer likes and dislikes. In addition, marketers must know what information will convince consumers to buy their product, and whom consumers perceive as a credible source of information. Some marketing strategies use fictional characters, celebrities, or experts (such as doctors) to sell products, while other strategies use specific statements or "health claims" that state the benefits of using a particular product or eating a particular food.

Impact and Influence

Marketing strategies directly impact food purchasing and eating habits. For example, in the late 1970s scientists announced a possible link between eating a high-fiber diet and a reduced risk of cancer. However, consumers did not immediately increase their consumption of high-fiber cereals. But in 1984 advertisements claiming a relationship between high-fiber diets and protection against cancer appeared, and by 1987 approximately 2 million households had begun eating high-fiber cereal. Since then, other health claims, supported by scientific studies, have influenced consumers to decrease consumption of foods high in saturated fat and to increase consumption of fruits, vegetables, skim milk, poultry, and fish. Of course, not all marketing campaigns are based on scientific studies, and not all health claims are truthful. In July 2000 a panel of experts from the U.S. Department of Agriculture supported complaints made by the Physicians Committee for Responsible Medicine that the "Got Milk" advertisements contained untruthful health claims that suggested that milk consumption improved sports performance, since these claims lacked scientific studies. Companies often use celebrity's characters to appeal to young consumers and common consumers. Currently, about one-fourth of all television commercials are related to food, and approximately one-half of these are selling snacks and other foods low in nutritional value. Many of the commercials aimed at children and adolescents use catchy music, jingles, humor, and well-known characters to promote products. The impact of these strategies is illustrated by several researcher studies showing that when a majority of television commercials that children view are for high-sugar foods, they are more likely to choose unhealthful foods over nutritious alternatives, and vice versa.

Inappropriate Advertisements

Attempts to sell large quantities of products sometimes cause advertisers to make claims that are not entirely factual. For instance, an advertisement for a particular brand of bread claimed the bread had fewer calories per slice than its competitors. What the advertisement did not say was that the bread was sliced much thinner than other brands. Deceptive advertising has also been employed to persuade women to change their infant feeding practices. Advertisers commonly urge mothers to use infant formula to supplement breast milk.

Marketing strategies include one strategy used by advertisers is to feature a celebrity in their advertisements or on their packaging. The implicit message is that the celebrity endorses the product, uses the product, and may even depend on the product for success. Many groups have objected to the use of marketing strategies that include free formula and coupons, and infant-formula manufacturing companies have been forced to modify their marketing practices.

Other marketing strategies involve labeling foods as "light," meaning that one serving contains about 50 percent less fat than the original version (or one-third fewer calories). For example, a serving of light ice cream contains fifty percent less fat than a serving of regular ice cream. As a result, consumers mistakenly believe that eating light food means eating healthful food. However, they fail to realize that a serving of the light version of a food such as ice cream can still contain more fat and sugar than is desirable.

Food labels with conflicting information often confront consumers. For example, labels claiming "no fat" do not 
necessarily mean zero grams of fat. Food labeling standards define low-fat foods as those containing less than 0.5 gram of fat per serving. Therefore, consuming several servings may mean consuming one or two grams of fat, and people are often unaware of what amount of a food constitutes a "serving." In addition, foods low in fat may be high in sugar, adding additional calories to one's daily caloric intake. Too often, consumers mistakenly translate a claim of "no fat" into one of "no calories."

It is also important for consumers to recognize their role in evaluating health claims and product comparisons. While advertisers are aware of the need for truth in advertising, sometimes their desire to sell products over-shadows an accurate disclosure of product attributes. Advertisers should bear in mind that inaccurate or vague health claims have the potential to cause economic hardship, illness, and even death. Lastly, marketing strategies used in developing nations should be subjected to the highest standards of truth in advertising.

So dairy marketing Strategies in the context of Globalization should be as:

1) Focused Approach: While the product portfolio has been growing, Indian dairy Industry should plan for reach out to newer markets - but the strategy here is more product-specific.

2) Wider Spread: However, as far as other dairy products are concerned, Indian dairy Industry should plan to expand across the board.

3) Create Original Marketing: Re-invent a product with a powerful marketing campaign. No matter if you are selling milk, yogurt, butter, sour cream, or cheese, a truly original commercial or print ad can cause consumers to think of your product in a new light. Whether you are conceiving of the marketing yourself or hiring a top advertising agency, aim for outside-of-the-box thinking. A catchy slogan, a memorable spokesperson or an emotionally powerful commercial can go a long way. Use viral marketing and social media to get your product to the masses without spending an enormous amount on advertising.

4) Focus on Nutritional Value: Use scientific-based guides and studies such as this to convince consumers to consume your dairy product. Associate your product with the study itself.

5) Appeal to the Organic Market: Consumer demand for organic milk continues to grow at an annual rate approaching 20 percent, according to the Agricultural Marketing Research Center. Many people are attracted to products that are free of chemicals and are manufactured naturally. Utilize the organic trend in your product line. Follow the government guidelines to get the organic seal to include in your product advertising and packaging.

6) Introduce New or Unknown Products: Offering consumers something they have never heard of is a sure-fire way to peak interest in a product. There were 448 total new dairy product launches in 2010, according to Dairy Foods. Consider creative yogurt flavors such as Yoplait's Apricot Mango and Dannon's Banana Cream Pie. Try new flavors of milk, such as banana or black raspberry, or varieties of cheese that are not well-known in the American market. Consider dairy products with added dietary supplements, such as probiotic, acidophilus or bifidus cultures

\section{Challenges \& Issues In DAiry MARKeting IN GloBAL CONTEXT}

Global marketing refers to the marketing activities that direct the flow of goods and services to the customers or users in more than one nation. Globalization is no longer an abstraction but a stark reality that virtually all firms, large and a small, face. Firms that want to survive in the 21 st century must confront this all encompassing force that pervades every aspect of business. In a wide range of industries from automobiles to food and clothing, firms face the pressures of global competition at home as well as in international markets. Choosing not to participate in global markets is no longer an option. All firms and industries regardless of their size, have to craft strategies in the broader context of world markets to anticipate, respond and adapt to the changing configuration of these markets. Firms initially entering international markets will be more concerned with learning about international markets, selecting an appropriate arena to compete, and determining how to leverage core competencies in international markets. Once in international markets, firms have to build their position in these markets, establishing a strong local presence by developing new products and adapting to local tastes and preferences. As the firm expands internationally, it will need to move away from country-centered strategies and improve integration and coordination across national markets, leveraging its competencies and skills to develop a leadership position.

In different markets, customer requirements may vary and the temptation to customize for each market has to be tempered by the need to keep costs down through standardization. A truly global marketing strategy would aim to apply uniformly some elements of the marketing mix across the world, while customizing others.

\section{KEY ISSUES IN DAIRY GLOBAL MARKETING:}

Typically, marketing includes the market research, product design, promotional activity, distribution, pricing and sales promotions etc. and some of these activities are agreeable to a uniform global approach. Others involve a great degree of customization. A global marketing strategy typically evolves over a period of time or phases-wise:

1) Decision to enter the market

2) The mode of entry.

3) To expand across several markets, simultaneously or one at a time.

4) Customization of the marketing mix or development of completely new products.

5) In the final phase, global companies examine their product portfolio across countries, strive for higher levels of coordination and integration and attempt to strike the right balance between scale efficiencies and 
local customization.

6) Entering new markets

While choosing new markets, MNCs need to consider several macro and micro factors.

Macro issues:

1) Political/regulatory environment,

2) Financial/economic environment,
3) Socio cultural issues and technological infrastructure. Micro issues:

1) Competitive considerations and

2) Local infrastructure such as transportation \& logistics network

3) Availability of mass media for advertising is important.

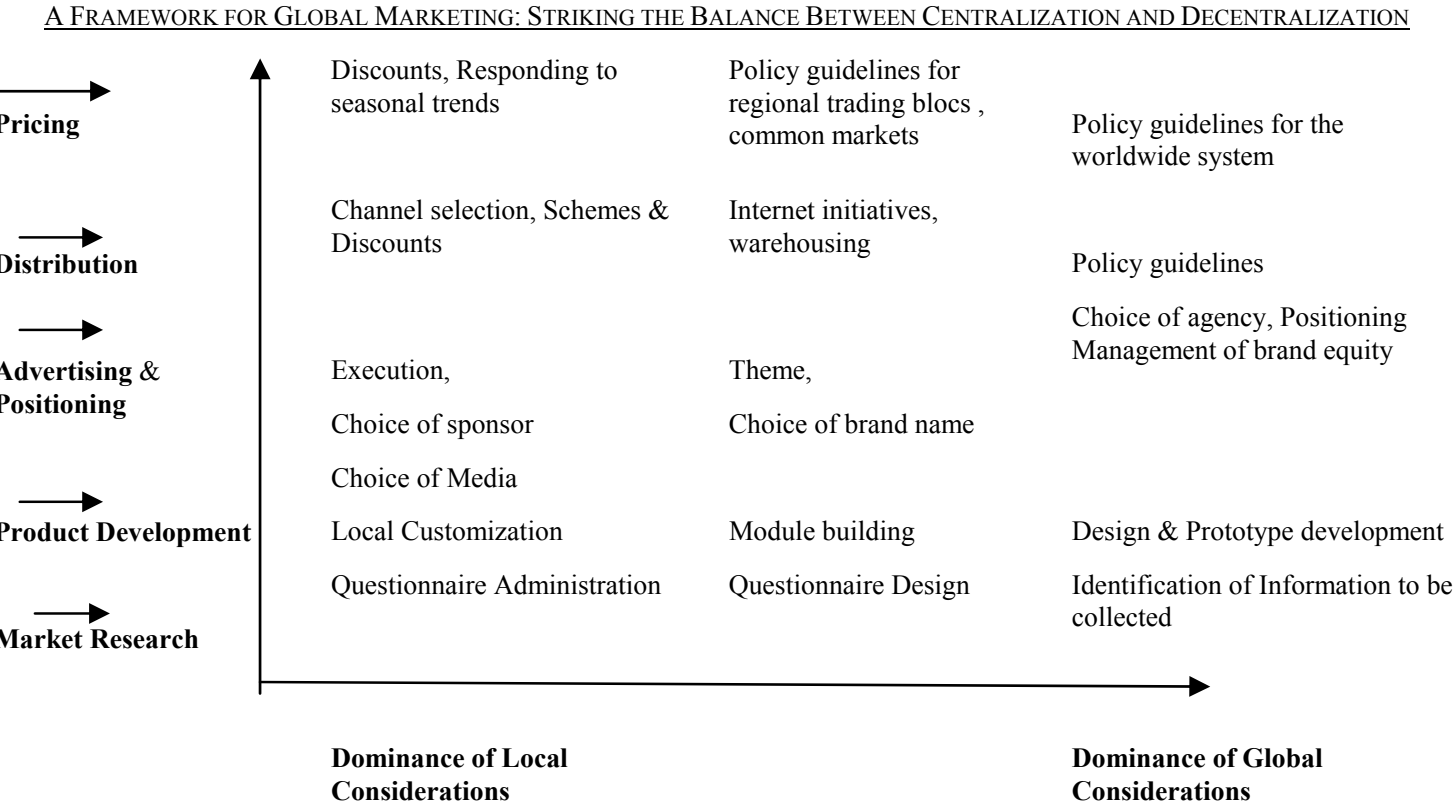

\section{CONCLUSION}

In order to increase the competitiveness of Indian dairy industry, efforts should be made to reduce cost of production, increasing productivity of animals, better health care and breeding facilities and management of dairy animals can reduce the cost of milk production. The Government and dairy industry can play a vital role in this direction. If India has to emerge as an exporting country, it is imperative that we should develop proper production, processing and marketing infrastructure, which is capable of meeting international quality requirements. A comprehensive strategy for producing quality and safe dairy products should be formulated with suitable legal backup. Apart from its performance there are some threats also exist we need to re-correct it and take the global market opportunities. Centralized marketing, centralized quality control, Centralized purchases and pooling of milk efficiently. Global marketing strategies have to respond to the twin needs of global standardization and local customization. In their quest to maximize local responsiveness, companies should not overlook opportunities to standardize and cut costs. On the other hand, an excessive emphasis on generating efficiencies through a standard marketing mix may result in the loss of flexibility. The challenge for global marketers is to identify the features which can be standardized and build a core product. In real life, striking the right balance between standardization and customization can be extremely challenging. Higher professionalism could be imparted in rearing, milking as also handling during distribution of milk. Lessons could be learnt by individuals and small dairy farms from the cooperative sector, which has managed to impart some amount of professionalism in its operations. Several areas in the dairy industry could be strengthened by induction of state-of- the-art technologies, transferred from other dairy majors of the world. Operational efficiencies are required, not only to improve yields but also to reduce waste and minimization of losses in fat, protein during milk processing. A review of dairy development in the country presents encouraging trends, in terms of milk production, per capita availability of milk, sources of milk production, as also accessibility of milk. Government policy has undoubtedly played an important role in achieving this magnificent success at the aggregate level, but all these have occurred under the regulated trade regime.

\section{REFERENCES}

[1] Andrews, N., I. Roberts and S. Hester (1994) "The Uruguay Round Outcomes: Implications for Agricultural and Resource Commodities" in Outlook 94, Proceedings of the National Agricultural and Resource Conference, held in Canberra on February 1-3; also published in World Commodity Markets Trade, Vol. 1, ABARE, Canberra, pp. 171-179.

[2] Belch, George E., and Belch, Michael A. (1995). Introduction to Advertising and Promotion: An Integrated Marketing Communications Perspective. Boston: Irwin.

[3] Boyle, Marie A., and Morris, Diane H. (1994). Community Nutrition in Action. St. Paul, MN: West Publishing.

[4] Chetley, Andrew (1986). The Politics of Baby Foods: Successful Challenges to an International Marketing Strategy. New York: St. Martin's.

[5] Connor, John M., et al. (1985). The Food Manufacturing Industries: Structure, Strategies, Performance, and Policies. Lexington, KY: D.C. Heath.

[6] Dandekar, V. M. (1980) "Introduction to the Seminar on Measuring Agricultural Growth" Indian Jl.of Agricultural Economics, 35 ( 2): $1-12$.

[7] Debroy, B., Jha B. and Pailwar V. (1996) India's Agricultural Exports in the Post-Uruguay Setup, a project report submitted to the National Council of Applied Economic Research, New Delhi. 
[8] Elder, John P. (2001). Behavior Change and Public Health in the Developing World. Thousand Oaks, CA: Sage.

[9] EPM Communications (1998). "TV Is the Most-Often-Used Source of Health Information." Research Alert 16:7.

[10] Food and Agricultural Organisation (FAO) Production Year Book, various issues.

[11] Food and Agricultural Organisation (FAO) Trade Year Book, various issues.

[12] Gandhi, V.P. and G. Mani (1995) “Average Monthly Per capita Consumption Expenditure" Indian Jl.of Agricultural Economics, 50 (3) 283-293.

[13] Goldberg, Jeanne P., and Hellwig, Jennifer P. (1997). "Nutrition Scientists in the Media: The Challenge Facing Scientists." Journal of the American College of Nutrition 16:544-550.

[14] Goldin I. and D. van der Mensbrugghe (1995) "The Uruguay Round: An Assessment of Economywide and Agricultural Reforms." Paper presented in a World Bank Conference on The Uruguay Round and the Developing Economies, World Bank, Washington D.C.

[15] Government of India (2002) Basic Animal Husbandry Statistics, published from Department of Animal Husbandry and Dairying, Ministry of Agriculture (GOI).

[16] Gupta P.R. (1996) Dairy India 1997, an edited book (5th edition) published in A-25, Priyadarshini Vihar, New Delhi-92.

[17] Hathaway, D.E. and Merlinda D. Ingco (1996) "Agricultural Liberalisation and the Uruguay Round" in Will Martin and L. Alan Winters (edited), The Uruguay Round and the Developing countries, Cambridge University Press, Cambridge.

[18] Jain, D. K. (1992) Food Demand Analysis in India , an unpublished thesis submitted to National Dairy Research Institute (NDRI), Karnal, India.

[19] Jeffrey, D. B.; McLellarn, R. W.; and Fox, D. T. (1982). "The Development of Children's Eating Habits: The Role of Television Commercials." Health Education Quarterly 9:174-189.

[20] Jha, Brajesh (2000) Indian Agriculture and the Multilateral Trading System, Bookwell, New Delhi.

[21] Jha, Brajesh (2002) "India's Tobacco Exports: Recent Trends, Determinants and Implications,"Indian Jl. of Agricultural Economics, 57(1): 53-64.

[22] Jha, Brajesh (2003) Indian Dairy in the Emerging Trade Order, an unpublished report submitted to the Institute of Economic Growth, Delhi -7 .

[23] Jha, Brajesh and B. Debroy (2000) “Towards Globalising Indian Dairy Sector" Asian Economic Review, 42(2): 306-319.

[24] Konandreas, P. (1999) "Next Round of Negotiations in Agriculture with Special Reference to Dairy Sector." International Symposium on International Prospects for Dairying in the Next WTO Negotiating Round, held at Buenos Aires, Argentina, June 3-4, 1999.

[25] Kumar, P. (1998) Food Demand and Supply Projections for India , Agricultural Economics Policy Paper 98-01, Indian Agricultural Research Institute, Pusa, New Delhi -12 .

[26] Lalwani, M. (1989) "Technological Change in India's Dairy Farming Sector: Distribution and Decomposition of Output Gains" Indian Jl. of Agricultural Economics, 44 (1): 55-66.
[27] Mathios, Alan D., and Ippolito, Pauline M. (1998). "Food Companies Spread Nutrition Information through Advertising and Labels." Food Review 21(2):38-44.

[28] Munshi K.D. and Kirit S. Parikh (1994) "Milk Supply Behavior in India: Data Integration, Estimation and Implications for Dairy Development" Jl. of Development Economics, 45(2): 201-223.

[29] Nestle, Marion. (2000). "Soft Drink 'Pouring Rights': Marketing Empty Calories to Children." Public Health Reports 115:308-319.

[30] OECD (2001) “OECD PSE/CSE Database 2001” Organisation for Economic Cooperation and Development (OECD), Paris.

[31] Radhakrishna R. and C. Ravi (1990) Food Demand Projections for India, Centre for Economic and Social Studies (CESS), Hyderabad, India.

[32] Ramesh Chand (1999) Liberalisation of Agricultural Trade and Net Social Welfare: A Study of Selected Crops, Economic and Political Weekly Vol. 34 (52): A153-159.

[33] Ratnam C. (1985) "Short Run Supply Functions of Milk: A Note" Indian Jl. of Agricultural Economics, 40(3): 517-519.

[34] Shankar Ravi (2003) "Policy and Regulations - Influencing Milk Producers" Indian Dairyman, 55(3): 96-100.

[35] Sharma V.P. and P. Sharma (2002) Trade Liberalisation and Indian Dairy Industry, Oxford and IBH Publishing Co. Pvt. Ltd. New Delhi.

[36] Sutton, Sharon M.; Balch, George I.; and Lefebvre, Craig (1995). "Strategic Questions for Consumer-Based Health Communications." Public Health Reports 110:725-733.

[37] Taras, H. L., et al. (1998). "Television's Influence on Children's Diet and Physical Activity." Journal of Developmental and Behavioral Pediatrics 10:176-180.

[38] Taylor, Anna (1998). "Violations of the International Code of Marketing Breast Milk Substitutes: Prevalence in Four Countries." British Medical Journal 316:1117-1122.

[39] Vaidyanathan A. (1986) "Labour Use in Rural India: A Study of Spatial and Temporal Variations" Economic and Political Weekly, 21 (52): A130-A146.

[40] World Bank (1998) "India: The Dairy Revolution (The impact of Dairy Development in India and the World Bank's Contributions)", by Candler Wilfred and Nalini Kumar, World Bank Operations Evaluation Department, The World Bank, Washington, D.C.

[41] Baker, Linda (2000). "Breast-Feeding vs. Formula Feeding: Message in a Bottle." Available from <http://www.zipmall.com/bab-bott.html $>$

[42] Center for a New American Dream. "Just the Facts About Advertising and Marketing to Children." Available from $<$ http://www.newdream.org/campaign/kids/facts.html $>$

[43] Infant Feeding Action Coalition (INFACT) Canada (2002). "Infant Foods and Health Claims." Available from $<$ http://www.infactcanada.ca/claimsfall1998.htm $>$

[44] Medical College of Wisconsin. "Health Claims on Food Labels: What Do They Really Mean?" Available from $<$ http://healthlink.mcw.edu/article/974663611.html>

[45] Optimal Wellness Center (2002). "USDA Confirms Milk Ads Make False Health Claims." Available from $<$ http://www.mercola.com/2001/oct/3/milk ads.htm>

[46] Dairy Marketing Strategy | eHow.com http://www.ehow.com/info_7785519_dairy-marketing-strategy.html\#i xzz1Bm1ORQRW(Accessed on 21 Jan 2011 at 7:30 pm) 